\title{
Quarry Waste: Chances of a Possible Economic and Environmental Valorisation of the Montorfano and Baveno Granite Disposal Sites
}

\author{
G. A. Dino, M. Fornaro, and A. Trentin \\ DST, Università degli Studi di Torino, Via Valperga Caluso, 35, 10125 Torino, Italy \\ Correspondence should be addressed to G. A. Dino, giovanna.dino@unito.it \\ Received 31 August 2011; Revised 15 November 2011; Accepted 16 November 2011 \\ Academic Editor: Atle Nesje
}

Copyright ( $\odot 2012$ G. A. Dino et al. This is an open access article distributed under the Creative Commons Attribution License, which permits unrestricted use, distribution, and reproduction in any medium, provided the original work is properly cited.

\begin{abstract}
The Montorfano and Baveno granite ore bodies are located in the Lake District (VCO-NE Piedmont). They were and are still quarried as dimension stones, with a consequent production of a huge volume of "waste." In 1995, an Italian company (GMM S.p.A) decided to invest in the valorisation of granite quarry waste as a secondary raw material. An in situ geological prospecting was carried out in order to evaluate the characteristics of the material and the thickness and volume of the useful disposal sites that could be used (by means of geophysical surveys). As a consequence of the field work, the amount of quarry waste was estimated as nearly $2 \mathrm{Mm}^{3}$. Chemical analysis was carried out on 75 granite samples, in order to individuate the $\mathrm{Fe}_{2} \mathrm{O}_{3}$ grade: from $1.321-$ $2.593 \%$ of the original waste to $0.160-0.228 \%$ after the "dry process" treatment. Three different detailed maps that show the typology, the locations, and the quality distribution of the material in the dumping areas have been drawn up.
\end{abstract}

\section{Geological Setting}

The main quarry disposal sites, the subject of the present research, are located in two different areas: the Sengio and Ciana Tane-Pilastretto dumps, which are located on the southern slope of the Montorfano Massif, while the Braghini site pertains to Monte Camoscio, on the right side of the Toce River (Ossola Valley) (Figure 1).

The two granitic plutons belong to the Hercynian Magmatic belt, which is located between the Ivrea-Verbano zone and the Serie dei Laghi unit. These units pertain to the South Alpine system basement and are situated to the south of the Insubric line. The Permian granites, Graniti dei Laghi, consist of nonmetamorphosed to weakly metamorphosed rocks $[1,2]$ and constitute an elongated SE-NW batholith, between the Biella-Valsessera and Val d'Ossola zones. This batholite is formed by singular plutons which develop a narrow contact aureole [3] in the Scisti dei Laghi and the Strona-Ceneri formation. The batholith is composed of five plutons: Biella-Valsessera, Alzo-Roccapietra, Quarna, Mottarone-Baveno, and Montorfano. Their age has been estimated, using a radiometric test, as $275 \mathrm{My}$ [4]. The study has focused on the Mottarone-Baveno and Montorfano plutons: these granitic bodies, NE-SW elongated, at present separated by quaternary deposits, occupy an area of about $30 \mathrm{~km}^{2}$ and intrude awkwardly into the Scisti dei Laghi unit.

The Mottarone-Baveno pluton is mainly formed by two different varieties of granite: a pink granite (called "Rosa Baveno," Table 1), a historically famous ornamental stone, which has been quarried in the district over the last centuries, and a white granite, which represents the prevalent volumetric variety in the pluton, and which is no longer quarried. The miarolitic granite, with a small percentage of even red granite, constitutes the upper layer of the pluton (this layer dips about $15^{\circ}$ to the $\mathrm{E}$ ): the transition from the white to the pink granite is mainly chromatic (Table 1 ) and is probably caused by chemical diadochy of the $\mathrm{Fe}^{3+}$, which substitutes the $\mathrm{Al}$ in the $\mathrm{K}$-feldspar structure [5]. The pink granite is characterized by the presence of intergranular albite and fluorite.

The Montorfano pluton is formed by a medium-grained white granite and a small amount of a "green granite." It is actually an episyenite consisting mainly of albite and chlorite. This so-called Verde Mergozzo occurs in the northern slope 
TABLe 1: Petrographic analysis of the Montorfano white granite and the Baveno pink granite.

\begin{tabular}{|c|c|c|c|c|c|c|c|c|}
\hline & \multirow{2}{*}{ Mineralogy } & \multicolumn{7}{|c|}{ Chemical composition } \\
\hline & & $\mathrm{Al}_{2} \mathrm{O}_{3}$ & $\mathrm{Fe}_{2} \mathrm{O}_{3}$ & $\mathrm{TiO}_{2}$ & $\mathrm{CaO}$ & $\mathrm{MgO}$ & $\mathrm{K}_{2} \mathrm{O}$ & $\mathrm{Na}_{2} \mathrm{O}$ \\
\hline Baveno pink granite & $\begin{array}{l}\text { Quartz, K-feldspar, plagioclase, biotite, zircon, } \\
\text { allanite and fluorite }\end{array}$ & 13,98 & 2,301 & 0,26 & 1,19 & 0,29 & 4,97 & 3,18 \\
\hline Montorfano white granite & $\begin{array}{c}\text { Plagioclase, quartz, K-feldspar, biotite, apatite, } \\
\text { zircon, allanite }\end{array}$ & 13,75 & 2,2895 & 0,25 & 1,25 & 0,265 & 4,875 & 3,225 \\
\hline
\end{tabular}

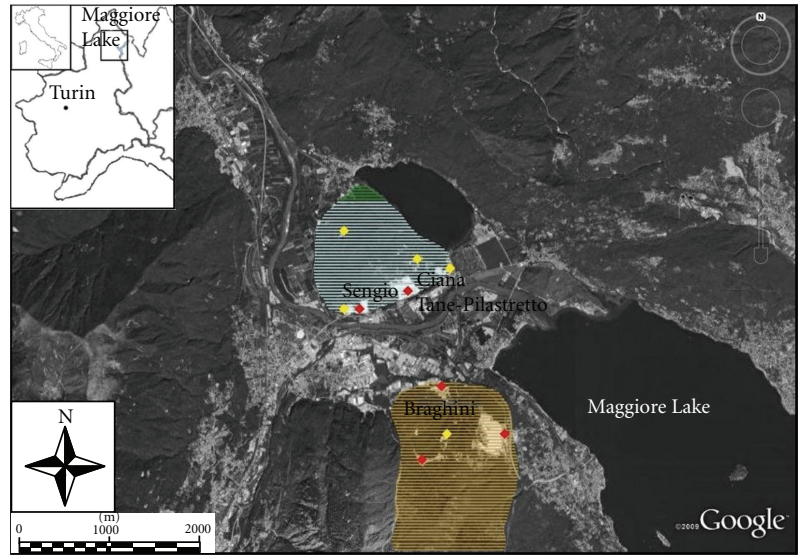

Figure 1: Geographic context of the studied area. The main image shows the satellite orthophoto of a portion of Massiccio dei Laghi batholith. In the northern part of the map (Montorfano area), it is possible to individuate both the white granite (represented by grey stripes) and the green granite portion (green Mergozzo type, represented by green stripes). The orange area defines the BavenoMottarone pluton. Furthermore in the image the exploited quarry dumps (red points) are represented and the ancient quarry waste areas, potentially useful for a future valorisation (yellow points).

of the pluton, where the unconformity with the Serie dei Laghi unit is evident (Figure 1).

The Montorfano massif is delimited by a complex structural fault system (Figure 2) [6]:

(i) the Gravellona-Fondotoce-Bieno fault, WSW-ENE oriented, divides the Montorfano from MottaroneBaveno massif,

(ii) the Candoglia-Mergozzo-Fondotoce fault, NNWSSE, corresponds to the major axes of the Mergozzo lake,

(iii) the Pogallo-Lago d'Orta fault, in the N-S direction, is in the western part of the pluton.

\section{Mining Context}

The studied granite resource was only quarried in the past for a local use: in the XVI century, production grew and the material was exported and used for the construction of important buildings and by manufactures in the neighbouring regions (above all the pink granite for Lazzaretto in Milan). The production increases even more during the XVII

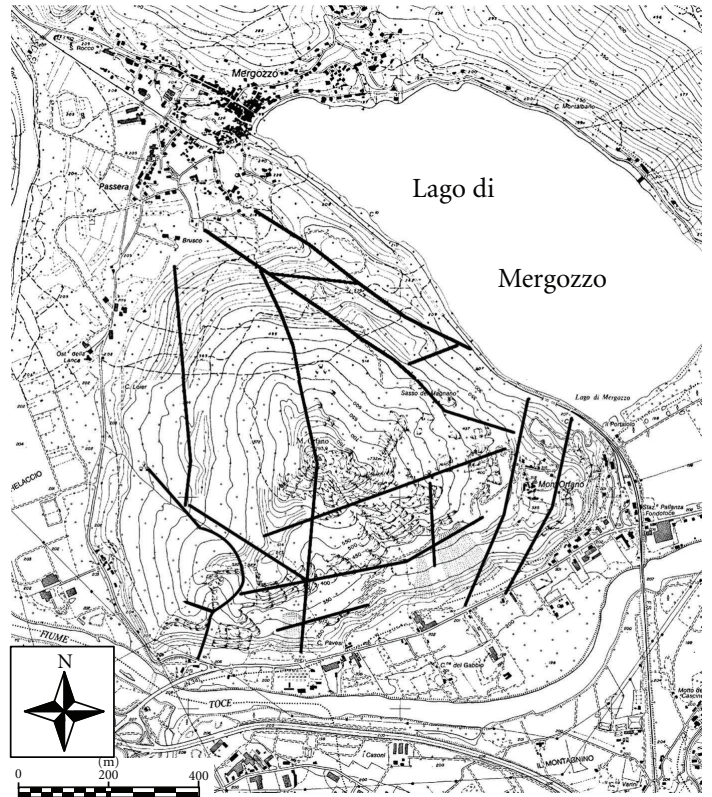

FIGURE 2: Structural sketch map of the Montorfano pluton, showing the main directions of the principal fracture systems and the main faults in the granite massif. These directions depend on the regional faults system (Gravellona-Fondotoce-Bieno, Candoglia-MergozzoFondotoce, and Pogallo-Lago d'Orta faults) [6].

century, thanks to the modernization of the exploitation technology and innovative quarry techniques (such as the extraction of megalithic blocks for use as columns for historical palaces and important churches).

In the XVIII and XIX centuries, the granitic structures and manufactures could be found throughout the North of Italy and even reached Rome; in 1830, 82 columns of Montorfano White Granite were sent to Rome, by means of river transport, for the realization of the famous Basilica of San Paolo Fuori le Mura. Baveno pink granite was also used for the realization of Christopher Columbus monument in New York and the King's palace in Bangkok.

The quarries were exploited using explosives (large charge rock blasting (large charge rock blasting, fired in small adits or tunnels, driven in the face of the quarry (at the level of the floor). Coyote shooting), [7]): the dimension stones, sectioned after the explosion, were placed in the quarry yard for the subsequent working phase. In the past, this excavation technique produced, during the past, a huge amount of waste, which were stocked on the lower side of the hill of the 


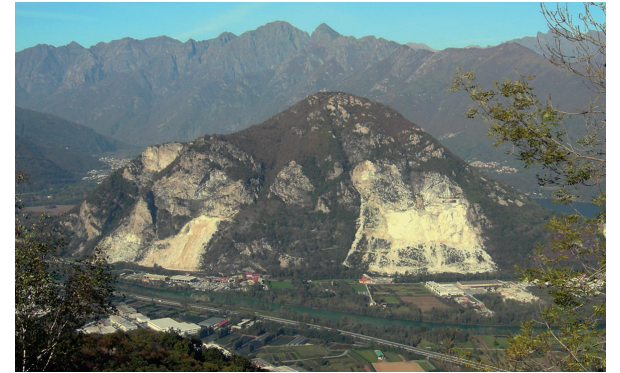

FIGURE 3: Southern side of Montorfano massif.

massifs (Montorfano and Baveno), thus forming differently shaped "waste" dumps ("ravaneti").

The volumes of quarry waste are a clear example of the problems connected to mining activities: the exploitation works in this territory have caused and are causing an evident hazard for the population, as well as significant environmental and landscape impacts on this rather touristic area (Lago Maggiore territory) (Figure 3).

Thanks to the evolutions in quarrying techniques, the quantity of waste has been reduced over the last few decades, but the problems connected to the management of such a kind of materials have remained unsolved. A possible way of solving the problem, with contemporary economic benefits, should be the new exploitation of the materials, stocked in dumps, for the production, by specific mineral dressing treatment, of secondary raw materials (SRMs) for industry (mainly for the production of Grès Porcelain stoneware) through specific mineral dressing treatments [8].

According to the regulations, the raw materials for the Grès Porcelain stoneware had to include pure quartz and feldspar; for this reason the price of the final product is expensive. The introduction of secondary raw materials from the exploitation of quarry waste from the Montorfano and Baveno granites, whose mineral composition (33\% quartz, $62 \%$ feldspar) is quite similar to the desired mixture, represents the basis for a new waste valorisation which nowadays represents an interesting economic reality which has produced a subsequent decrease in the costs of the raw materials.

The feldspar market, as an industrial mineral, has increased year after year in Italy: from $200.000 \mathrm{t}$ in 1975 to $2,5 \mathrm{Mt}$ in recent years (2005 data); the imported natural resources (about 2,0 Mt) have to be added to these amounts. Some industrial mineral factories, such as Ecomin S.p.A. (Ecomin is one of the companies of Gruppo Minerali Maffei S.p.A Group) in Verbania, decided to produce SRM from granite quarry waste.

This treatment plant, which has operated in the field of dressing of raw material since 1995, has the concession to exploit the three granite quarry waste disposal sites: the Sengio and Ciana Tane-Pilastretto areas (white granite) and Braghini area (pink granite exploitation).

In order to guarantee the highest level of safety in the overhanging yards and the stability of the quarry fronts, the material layer is exploited from the top to the bottom of the whole volume: the quarried material is then loaded into dumpers and transported to the treatment plant. The large-sized blocks that are stocked in the areas are reduced using blasting and breaking techniques, or are used, as such, as riprap or armour stones. The total recovery of the granite waste has exposed the underlying bedrock, in order to minimize the hydrogeologic hazard in the area.

The ore, conveyed from the quarry waste areas to the plant, is treated by crushers, roller mills, and so forth, in order to reduce each grain size class and to obtain $1.25 \mathrm{~mm}$ as the maximum grain size dimension. It is then sieved to obtain different grain size materials and to separate the powder granite from the other products. Finally this material passes through electromagnetic separators, which select the ferromagnetic minerals from the final product, characterized by appropriate physical-chemical properties. The waste produced during the enrichment phase (powder granite, ferromagnetic minerals, mud) is also treated to obtain byproducts which are used in other applications.

In particular, the main product is commercially known as F60P (quartz feldspar mixture: $60 \%$ of feldspar, mostly $\mathrm{K}$-feldspar), whose production is about 140.000 t/year. Different byproducts, commercially known as SNS-sand (as a premix for building uses), NGA-coarse black sand (used for industrial sandblasting), SF-wet feldspar (for the ceramic industry), and SF100 and SF200 (used as fillers in cement industries), have to be added to the F60P production. The total amount of byproducts is about 70.000 t/year.

The importance of such a treatment is that, at first, it is possible to valorise quarry waste as secondary raw material, and then it is possible to achieve the goal of a zerowaste-volume production, with a consequent reduction ins costs for quarry enterprises and indisputable environmental advantages for the territory.

The Gruppo Minerali Maffei S.p.A has carried out different geo-mechanic stability controls on the slopes and has characterised the three exploited areas, in order to establish the possibility of rock detachment, both from the mountain faces and from the debris landfill (debris flow and/or rock collapse).

As far as the modelling of the potential gravitational dynamics is concerned, an ILA programme, which allows the safety factor (Fs) values to be calculated, on the basis of common stability models (Bishop, Jambu, etc.), was adopted. The parameters used to calculate the Fs are summarised in Table 2.

On the basis of the reported data, it was possible to calculate the Fs (December 2004) for the three areas and to foresee the Fs in 5 (December 2009) and 10 years (December 2014), see Table 3.

The Fs value was obtained considering the different heights of the rock face (granitic basement), considering a hypothetical rock collapse from different altitudes, and also considering the "in-progress" mining activity (on the granite debris).

The evaluated Fs values, connected to geomechanic stability of the debris deposits, are very close to the equilibrium limit. Moreover, it is possible to underline that the Fs pertaining to the mining exploitation of the quarry waste 
TABLE 2: Quarry dumps characteristics (granite substratum and debris landfill).

\begin{tabular}{|c|c|c|c|c|c|c|c|}
\hline & \multicolumn{2}{|c|}{ Sengio area } & \multicolumn{2}{|c|}{ Ciana-Tane Pilastretto area } & \multicolumn{3}{|c|}{ Braghini area } \\
\hline & $\begin{array}{c}\text { Granite } \\
\text { substratum }\end{array}$ & $\begin{array}{l}\text { Debris } \\
\text { landfill }\end{array}$ & $\begin{array}{c}\text { Granite } \\
\text { substratum }\end{array}$ & $\begin{array}{l}\text { Debris } \\
\text { landfill }\end{array}$ & $\begin{array}{c}\text { Granite } \\
\text { substratum }\end{array}$ & $\begin{array}{l}\text { Debris } \\
\text { landfill }\end{array}$ & $\begin{array}{l}\text { Eluvio-colluvial and } \\
\text { fluvio-glacial deposits }\end{array}$ \\
\hline Saturated volume weight $\left(\mathrm{kN} / \mathrm{m}^{3}\right)$ & 25 & 18.5 & 25 & 18.5 & 25 & 18.5 & 20 \\
\hline Not drained cohesion $\left(\mathrm{kN} / \mathrm{m}^{3}\right)$ & 0 & 0 & 0 & 0 & 0 & 0 & 0.1 \\
\hline Internal friction angle & $45^{\circ}$ & $38^{\circ}$ & $45^{\circ}$ & $38^{\circ}$ & $45^{\circ}$ & $38^{\circ}$ & $28^{\circ}$ \\
\hline
\end{tabular}

deposits (in the studied areas) increases more and more over the years.

The data reported in Table 3 confirm, once again, that mining exploitation of the granite quarry disposal sites (new mines) significantly improves the geomechanical stability of the investigated areas.

What emerges from the shown data (Table 3 ) is that in December 2004, and not considering regular mining exploitation and contextual slope recovery, the safety factor (Fs) was very close to the limit imposed by law (Fs = 1.3; Ministerial Decree 11/03/1988). It is possible to underline that the current configuration of the debris body is suitable for a stable equilibrium over the long term. Thanks to the mining exploitation, the stability of the slope (rock with a very little part of debris material) will improve more and more (see Table 3 ).

\section{Waste Valorisation}

3.1. Geological Survey. The present study illustrates a detailed geological and geomineral survey of the three mining areas, which was focused mainly on the granite waste deposits and on quaternary formations (fluvial and glacial deposits), in order to delineate their geometric surface.

Furthermore, the research described the structural, granulometric, and stability properties of the waste deposits and, at the same time, conducted a petrologic characterization of the bedrock, with the purpose of underlining the general characteristics (petrology, size distribution, morphology of the bedrock, and stability of the slopes) of the three deposits. This data collection is useful to describe the general characteristic of the waste deposits, compared to the adjacent areas, in order to evaluate the volume of the ore bodies, using surface and thickness data (see Section 3.2). One of the goals of the study was to evaluate the past environmental rehabilitation measures conducted in the past in some dumps and the development of the future rehabilitation measures in the three investigated areas.

The granite waste (Figure 4) is composed of $>30 \mathrm{~mm}$ material $(70-75 \%),<30 \mathrm{~mm}(20 \%)$, and metric rocks (5 to $10 \%)$ : it is classifiable as a granitic gravel sand, with a small percentage of silt and the absence of clay. The presence of the silt fraction is caused by weathering of the granitic sand and gravel. Only metric boulders are formed, above all, by white and/or pink granites, in the Braghini area.

The Sengio white granite deposit (Figure 1) has a particular characteristic, which has been observed only in this massif sector: in the rock volume, some millimetric femic

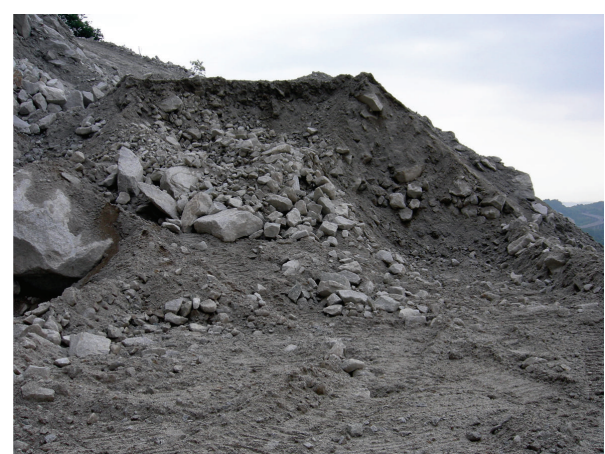

FIGURE 4: Granite quarry waste detail. The different, casual grain size distribution compromise the stability of the coarse volume.

concentrations $(\max 2 \mathrm{~cm})$, characterized by an oxidized ring around the femic masses, are recognizable in the rock volume. This globular femic concentration has been described by some authors as a globular dissemination of arsenopyrite mineral [9] which causes an important decrease in the final quality of the product.

The femic masses are frequently the cause of the lower quality of the dimension stone; therefore, a large quantity of waste was produced in the Sengio area during exploitation. When the orebody became uneconomic, because of the decrease in quality, the mine conductor abandoned the quarry and transferred the exploitation to the SE area.

The Ciana Tane-Pilastretto (Figure 1) name originates from the presence of Ciana and Tane-Pilastretto quarries, at the top of the granitic waste dumps. A huge quantity of waste (more than in the Sengio area) covered the area, because the Ciana and Tane-Pilastretto quarries were exploited for a longer period, thanks to the better quality of the granitic orebody (characterized by lower femic disseminations in the inner plutonic position).

The Ciana Tane-Pilastretto granitic waste is formed by metric blocks in the superficial layer and sandy to gravel materials in underlying volume, which can be observed from the road that cuts the middle sector of the dump. The granulometric fractioning is caused by the mobilization of the metric boulders that have been left on the superficial layer, above all from the top of the granite waste exploitation.

The Braghini dump (Figure 1) is instead formed by pink granite clasts coming from the Monte Camoscio quarries: the main minerals are quartz, pink to red K-feldspars, plagioclase, and biotite. The materials occupy the basal part of the slope, partially blocking the flow of a stream. 


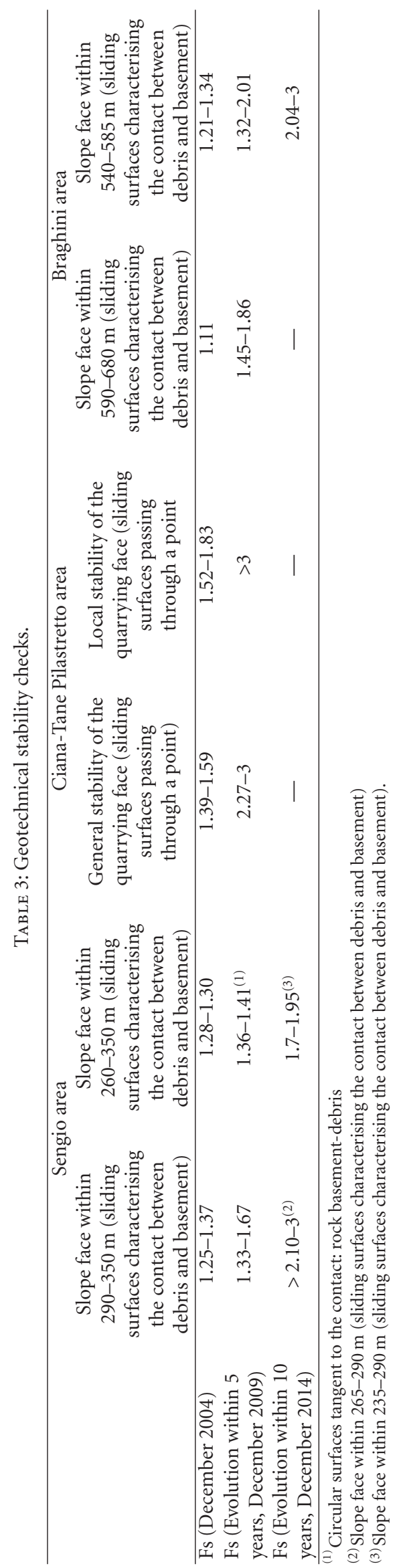




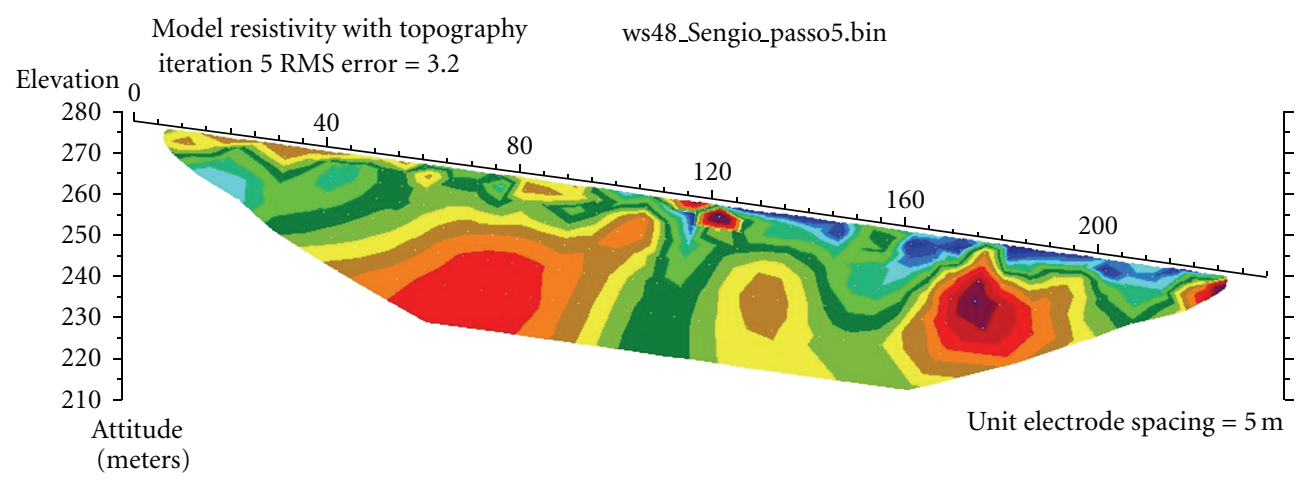

(a)

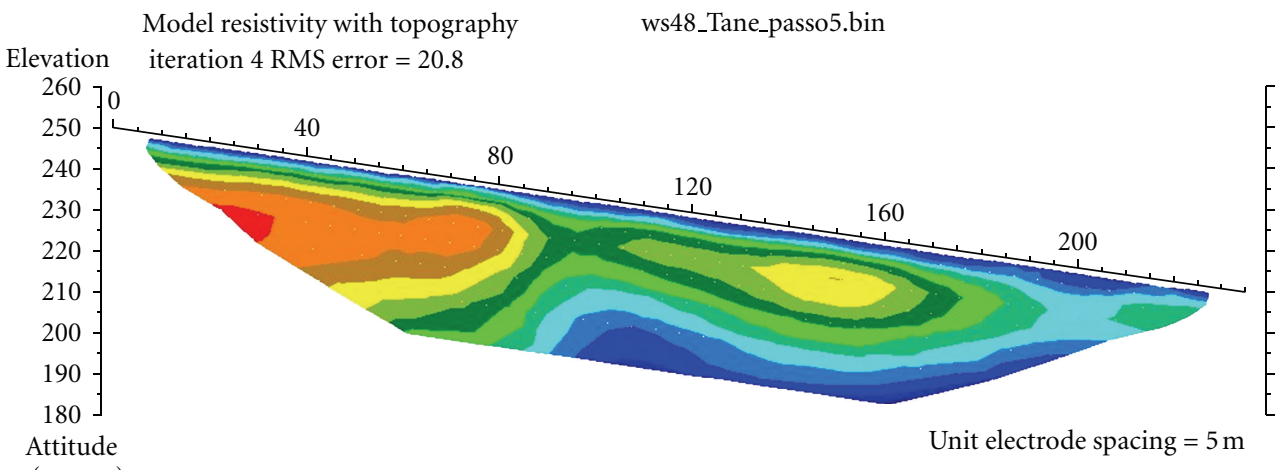

(b)

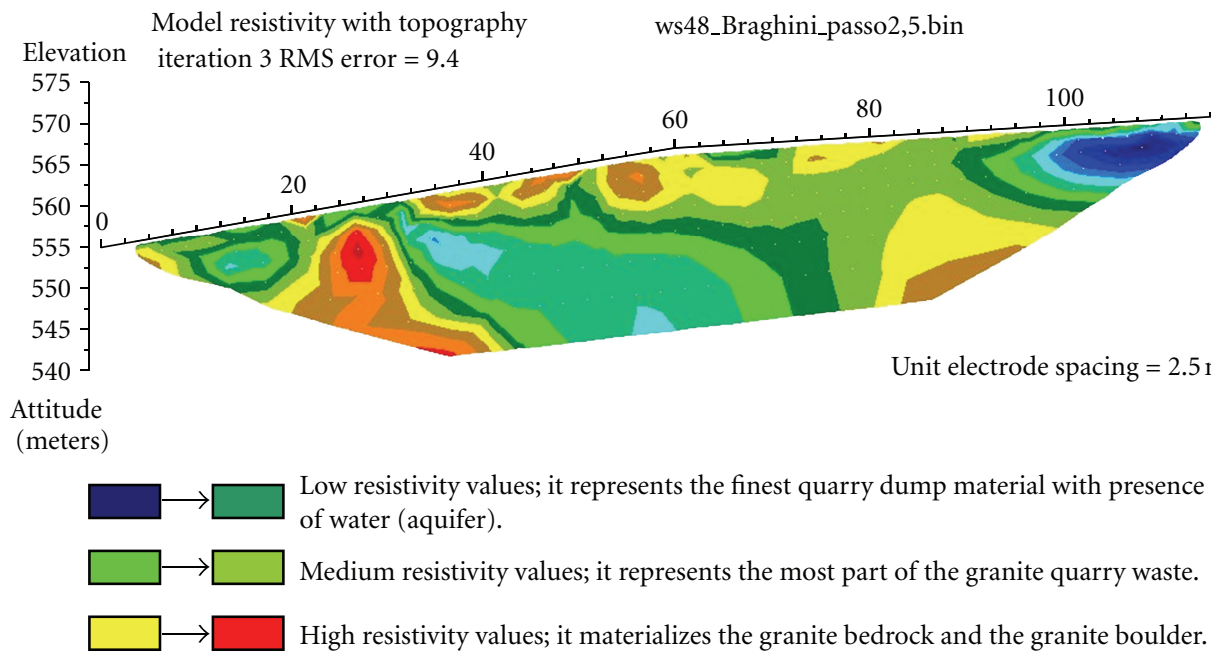

(c)

Figure 5: (a) Sengio area. (b) Tane Pilastretto area. (c) Braghini area.

An important characteristic of the waste, when considering it as raw materials for ceramic industries, is the different weathering alteration of the sandy fractions, caused by the different steps of the granite waste during the centenarian activity: the vegetation is also composed of different plants because of the different periods of deposition. This factor is very important when deciding, projecting, and programming the best way to valorize the materials in a treatment plant.
3.2. Volumes Determination. Another goal of the study was to determine the volumes of the ore bodies: a geophysical survey - an electrical tomography investigation-was carried out to estimate the thickness of the waste deposits. Thanks to a processing phase, the collected field data (resistivity data) were processed to obtain a resistivity model of the investigated area and a 2D resistivity cross-section.

In the Sengio area (Figure 5(a)), the tomography track is positioned in the median sector of the dump, through 
TABLE 4: Thickness and volumes for the investigate areas.

\begin{tabular}{lcc}
\hline $\begin{array}{l}\text { Quarry waste } \\
\text { dumps }\end{array}$ & $\begin{array}{c}\text { Average thickness calculated } \\
\text { thanks to tomography } \\
\text { cross-sections }(\mathrm{m})\end{array}$ & $\begin{array}{c}\text { Ore body } \\
\text { volume }\left(\mathrm{m}^{3}\right)\end{array}$ \\
\hline $\begin{array}{l}\text { Sengio } \\
\text { Ciana }\end{array}$ & $20 \mathrm{~m}$ & 361.600 \\
$\begin{array}{l}\text { Tane-Pilastretto } \\
\text { Braghini }\end{array}$ & $25 \mathrm{~m}$ & 1.489 .000 \\
\hline
\end{tabular}

an internal working road that crosses the whole volume. The distinctive parameters for the geophysical survey were 5 meters of electrode distance to obtain a length of 240 meters and a sampling rate of $250 \mathrm{~ms}$.

The same configuration as that of the Sengio area was used in the Ciana Tane-Pilastretto (Figure 5(b)) area. In this area the position of the cross-section was set in the basal sector of the waste volume.

Finally, in the Braghini dump (Figure 5(c)), the tomography cross section was set at a N-S direction, crossing the waste area in the lowest sector of the deposit; in this case the configuration of the survey was 48 electrodes, at the distance of 2.5 meters for every electrode, with a total section of about 117.5 meters.

It is possible to show the tomographic profiles of the three studied dumps (Figure 5). The considerable grain size distribution of the material conditioned the electrical signal answer. Even so, the configuration and the border between the waste deposit and the substratum of rock are clearly visible.

It is possible to estimate the deepness of the granitic bedrock in the cross section, thanks to the use of different colours, which correspond to different resistivity values. The resistivity difference can be related to the unconformity of the granitic waste and bedrock.

A comparison between the tomography cross sections and the geological surveys data made it possible to estimate the thickness of the waste deposits.

Elaborating the parameter reported in Table 4, it is possible to estimate a total volume of the dumps as about $2 \mathrm{Mm}^{3}$ (about 3.6 Mt). About 20\% has to be subtracted from this volume as it was selected in the treatment plant as not being directly utilizable as second raw material for ceramic. This material has in fact to be treated in another plant (as byproduct). Therefore, the resources directly treatable in the Ecomin plant should be about 2,9 Mtons. Considering a feeding to the plant of nearly $200 \mathrm{t} / \mathrm{year}$, it is possible to estimate, at least, 15 years for the production lifetime.

It is important to underline that the waste amount in the old quarry dumps is periodically refilled by the flowing waste and that the research for "new ore bodies" is still in progress. Therefore a longer treatment plant activity can be hoped for.

3.3. Laboratory Phase. After a geological survey a representative sampling on the debris deposit was carried out. The material characterised by a size distribution of 30 to

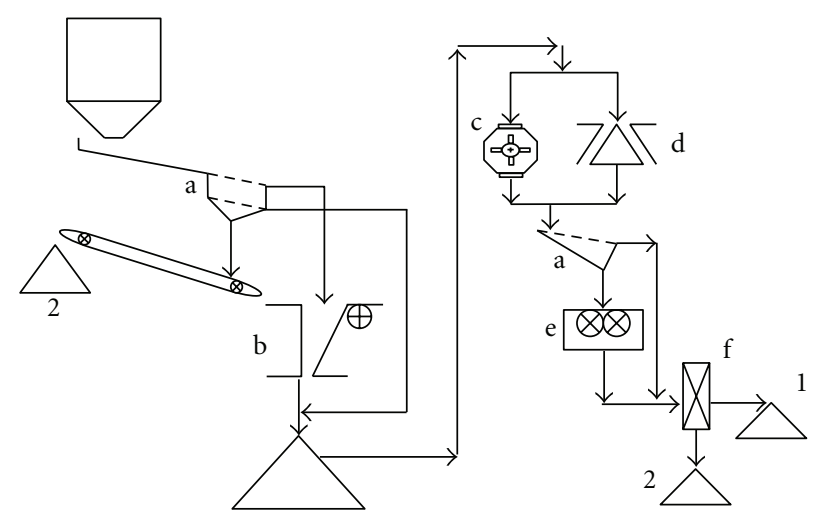

a: sieves

b, c, d: crushers

e: mill crushers

f: magnetic separation (different steps)

1: main product (F60P)

2: by products

Figure 6: Simplified flow-chart of Ecomin transformation plant.

$150 \mathrm{~mm}$ was sampled: $30 \mathrm{~mm}$ is the lower limit of the "stone chips" (debris rocks) which can be treated directly in the transformation plant (Ecomin).

Each area of the Sengio and Ciana-Tane Pilastretto quarry dumps was split into a square net of about $50 \mathrm{~m}$ per side, while the Braghini quarry dump was divided into a net of about $30 \mathrm{~m}$ per side.

78 samples were taken in the three studied dumps: 26 samples from the Sengio quarry dumps, 30 from the Ciana Tane-Pilastretto area, and 22 from the Braghini area. The samples were treated and analysed in the Minerali Industriali Lab. (Cacciano-Masserano, BI).

The laboratory treatment involved a simulation of the ore dressing pilot plant to what normally happens in the Ecomin treatment plant (Figure 6); in particular the process in the pilot plant (Figure 7) can be summarised as a progressive crushing (by means of jaw crushers and roller mills) in order to guarantee a size cut. The thus obtained material (TQ) was then treated by means of two passages in a magnetic separator with permanent magnet cylinders, in order to obtain the final product $(2 \mathrm{SM})$. The $2 \mathrm{SM}$ samples were grinded and compressed to create tablets for the chemical analysis, using an X-ray spectrometer (Siemens SRS 303). Also the TQ samples were also analysed (chemical analysis), in order to individuate the characteristics of the granitic rocks.

Chemical analyses are fundamental to evaluate the $\mathrm{Fe}_{2} \mathrm{O}_{3}$ grade of each dumps; this parameter is necessary to calculate the quality of the expected products from the treatment plant. On the basis of the lab results, it was possible to draw up, for each investigated area, a $\mathrm{Fe}_{2} \mathrm{O}_{3}$ grade map in order to individuate the zones characterised by the best quality (Figure 8).

In Figure 8 there are three maps concerning the geo-ore deposit quality in each studied areas. 


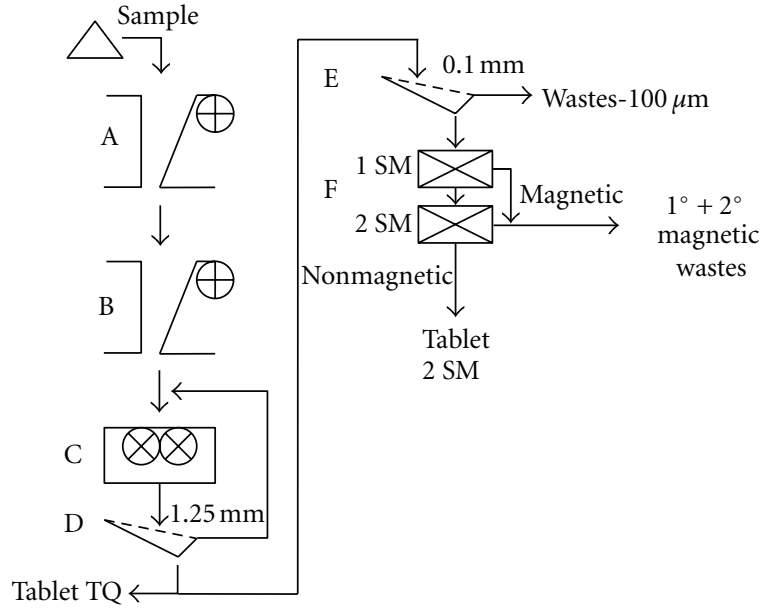

A, B: alternative crushers

C: mill crusher

D,E: laboratory sieves

F: magnetic separation (different steps)

FIGURE 7: Simplified flow-chart for the laboratory pilot plant.

TABLE 5: $\mathrm{Fe}_{2} \mathrm{O}_{3}$ average grade for the three studied areas.

\begin{tabular}{lcc}
\hline Quarry dumps & $\begin{array}{c}\text { Average grade } \\
\% \mathrm{Fe}_{2} \mathrm{O}_{3} \text { (TQ) }\end{array}$ & $\begin{array}{c}\text { Average grade \% } \\
\mathrm{Fe}_{2} \mathrm{O}_{3}(2 \mathrm{SM})\end{array}$ \\
\hline Sengio (white granite) & 2,317 & 0.205 \\
Tane-Pilastretto (white granite) & 2,262 & 0,184 \\
Braghini (pink granite) & 2,301 & 0.210 \\
\hline
\end{tabular}

The $\mathrm{Fe}_{2} \mathrm{O}_{3}$ grade was quite different (Table 5); the decrease of the quality in the Sengio and Braghini samples, after the magnetic separation, is probably caused by the particular physical characteristics peculiar of the material stocked in the two deposits.

In the Sengio quarry dump, the presence of altered arsenopyrite concentrations in the rocks is probably the reason for the bare magnetic separation during the treatment. On the other hand, the decrease in the quality of the final products in the Braghini quarry dump is probably caused by the weathering alteration in the fine matrix of the granite waste deposit, which compromises the magnetic separation.

Furthermore, looking at the three maps, it is possible to see that there are different $\mathrm{Fe}_{2} \mathrm{O}_{3}$ grades, even in the same dump area, which depend on the progressive waste stockpiling in dumps over the years (from different exploited areas). The data regarding the $\mathrm{Fe}_{2} \mathrm{O}_{3}$ grade distribution in the three areas are essential to guarantee the integral exploitation of the "waste resources" and to assure a controlled and uniform feeding to the treatment plant.

The lab testing phase also regarded the search for the right method to decrease the $\mathrm{Fe}_{2} \mathrm{O}_{3}$ grade in the samples characterised by a very low quality; in these cases a deeper crushing and adding magnetic separations would be the correct ways to valorise the material. On the basis of the test results, it is possible to notice a quality increase in the quality of treated material, in particular in the $0.1-0.5 \mathrm{~mm}$ size distribution classes.

As far as the efficiency of the magnetic separation in a future experimental phase is concerned, it is possible to notice that the $\mathrm{Fe}_{2} \mathrm{O}_{3}$ grade does not decrease substantially after the passages in the separator (3-4 passages): in fact the grade tendency is close to an asymptote. Such a result, directly imputable to the liberation grade of the single grains, is closely connected to the size distribution of the final product.

\section{Quarry Dumps Rehabilitation}

The old dumps can be considered as "new mines": they can be rehabilitated during the exploitation phase by the enterprise which owns the mining concession [10].

The valorisation of the material stocked in the dumps guarantees positive results, both for the company (ECOMIN) and the interests of the community at large. The systematic exploitation of the "waste" accumulated during the years and/or actually produced is the basic condition for

(i) the safety of the landfill areas, intervening with appropriate accommodation and environmental recovery,

(ii) the impacts reduction (dust, etc.), due to the presence of incoherent material placed on the dump slopes,

(iii) a positive economic return, due to the exploitation of the material placed in the dumps, which should not be quarried (with explosives and/or mechanical equipment), but only picked up and sent to the treatment plant.

Projects concerning "land use changes in areas characterised by hydrological constraints" have been approved, as far as the exploitation plans are concerned. As a result, the project envisages the exploitation of debris materials stocked on the slope, in order to reach the granite substrate (Figure 9). In parallel to the exploitation, an environmental restore of the areas has had to be carried out, at the same time as the exploitation. It offers a partial renaturalization of the site, in order to return it to its original morphological and landscape configuration, by reducing the visual and environmental impacts. In fact, thanks to appropriate naturalistic interventions, it is possible to recreate the typical environmental conditions typical of the quarried area before the exploitation. An additional and equally important objective of mitigating risk is to improve the stability of the dump slopes. Specific forced re-naturalisation interventions were carried out in some areas, which are completely free of debris material and characterised by high slopes: small terraces, built directly onto the granite substrate, on which top soil have been placed to encourage growth. Bush species were then implanted in these artificial inlets, with very good results (which should be verified in the future).

Other well-known forced "bio-engineering" re-vegetation methods were used for the reclamation of the areas [11]. The result is an rehabilitation that has been applied 


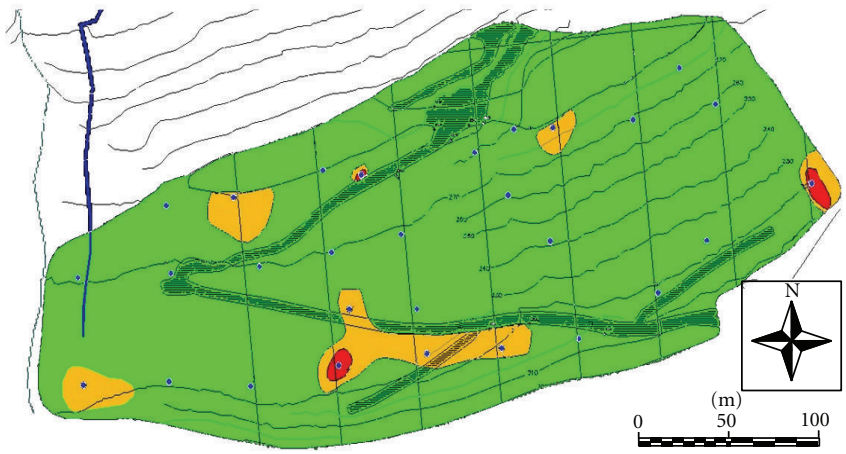

(a)

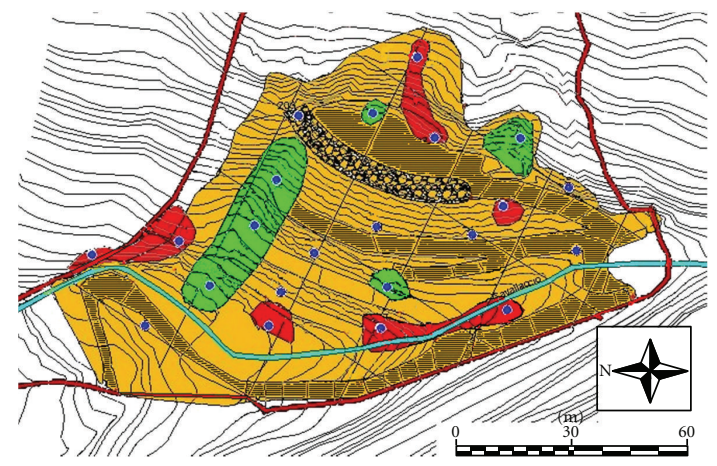

(b)

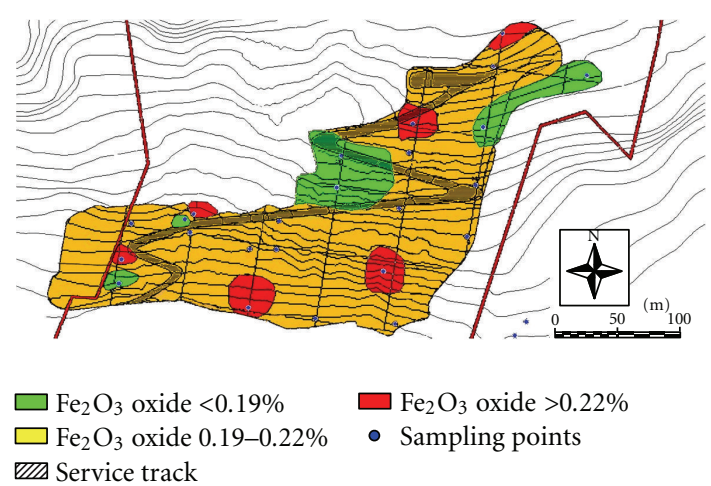

(c)

Figure 8: (a) Ciana-Tane Pilastretto Area. It is possible to notice the service track, in the middle of the quarry dump (black line), and a stream in the upper left side of the map (blue line). (b) Braghini Area. It is possible to notice, in the middle of the map, a rockfall protection embankments (wire netting area), the Rio Cavallaccio stream just above the rockfall protection embankments (blue line) and the concession area borders (red lines). (c) Sengio Area. Just in the middle of the investigated area it is represented a service track (black line). The borders of the concession area are portrayed as red lines.

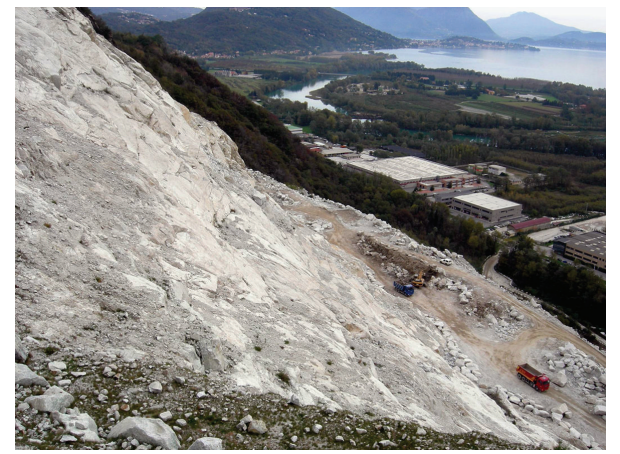

FIGURE 9: The uncovering of granite substrate thanks to mechanical equipments. The material is transported to the plant, located just below the slope (on the other side of the street).

perfectly to the morphological and vegetation context if the surrounding areas (see Figure 10).

The key elements, necessary to achieve the total safety conditions, seem to be the "walls" that have been placed at the base of the excavation, and which have been made using the less valuable material produced during the exploitation. These artificial hills are frequently useful to create a "screen" or a visual impediment to the outside world, in harmony with the surrounding nature. They are also important as protection elements for the adjacent and very busy SS34 (State highway, Figure 2).

The frequent fall of large amounts of water, due to the heavy rainfall that periodically affects the area, constitutes a repeated and hard test for the stability of the faces, which are often bares and characterised by the presence of incoherent materials.

Therefore, it is possible to ask, what would have happen to the safety of roads, sides, and so forth, if the miner had not decided to intervene, and to exploit the Baveno and Montorfano "waste-deposits." The exploitation of these materials is truly favourable for slopes stability and for the safety of the roads and infrastructure near the quarries.

A wise and planned mining activity is also important for the defence of the territory, as well as for the production of secondary raw materials (MPSs), which are profitable for the company and for the country.

\section{Conclusions}

The paper emphasizes that the interest of private companies for the systematic recovery of quarry waste should be 


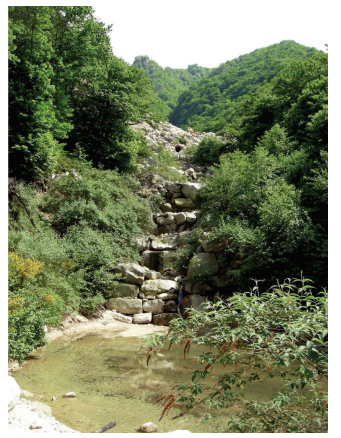

(a)

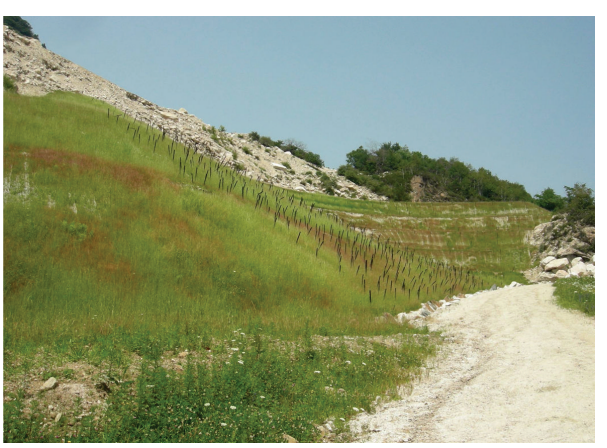

(b)

FIGURE 10: (a) Quarry dump rehabilitation (Braghini area). (b) Quarry dump rehabilitation after the exploitation of the pink granite waste, in order to obtain secondary raw material for ceramic industries. Scala dei Ratti yard (Baveno area), quarried by Mineral Baveno s.r.l.

interpreted as a signal of the good will of private and public bodies to guarantee environment and territory protection and the safety of the quarries.

The research points out that it is possible to ensure sustainable development for mining activities, guaranteeing, at the same time, profit for the virtuous companies involved in the exploitation, valorisation, and recovery of the "new ore-bodies."

In particular, treating and valorising the waste stored in quarry sites, it is possible to guarantee

(i) fewer (with less impact) problems concerning environmental impact and hydrogeological problems connected to quarry dumps,

(ii) greater slope stability,

(iii) to bring to surface other parts of the granite ore body, which were hidden by waste piles,

(iv) potential revenues from the treatment of MPS exploited from the dump/ore body, and so forth.

Granite quarry wastes represent, therefore, an important alternative (integrating) source, as a substitute to the exploitation of "virgin" material from the primary quartz and feldspar mines.

As already mentioned, the exploitation of the quarry waste often ensures a correct environment recovery and the safety of slopes affected by the dumps.

In order to fully exploit the granite resource from the dumps it is still essential to conduct a complete investigation in order to estimate the volumes, size distribution and chemical and mineralogical characteristics of the material.

The research should involve both a field investigation (detecting geostructural remote land sensing, geophysical surveys, etc.) and a weighty part of lab analysis (mineralchemical characterization of the raw material as such and of the products obtained from the treatment, ore enrichment in a pilot plant, etc.).

Thanks to a detailed study of the Graniti dei Laghi area (Baveno and Montorfano), it has been possible to

(i) calculate the quantity of material available for the treatment plant (2,9 Mtons), (ii) assess the quality of these materials in order to select what to send to the treatment plant and what to keep separate, because of their poorer quality. This unusable fraction should also be used for environmental recovery and the rehabilitation of the landfill morphology,

(iii) evaluate the reserves available in dumps, added to a coming waste from the quarry, which will ensure the productivity of the treatment plant for not less than 15 years.

\section{Acknowledgments}

The authors would like to thank the Gruppo Minerali Maffei S.p.A., Ecomin s.r.l, and Minerali Industriali S.p.A. for their fundamental help during the field surveys and the laboratory phase; a special thanks are due to Eng. G. Bozzola, Dr. T. Mestriner, Eng. E. Salvaia, Dr. A. Lorenzi, and Dr. S. Vegis. Thanks are also due to Prof. A. Godio and the Geophysics Lab at DITAG-Politecnico di Torino, for their help during the geophysical processing. Finally, they would like to thank Rag. D. Marchetti (Giacomini S.p.A. enterprise) for the kindness during the visit to the Mineral Baveno quarrying area and treatment plant.

\section{References}

[1] A. Boriani, L. Burlini, V. Caironi, E. Giobbi Origoni, A. Sassi, and E. Sesana, "Geological and petrological studies on the Hercynian plutonism of Serie dei Laghi-geological Map of its occurrence between Val Sesia and Lago Maggione (N-Italy)," Rendiconti-Societa Italiana di Mineralogia e Petrologia, vol. 43, no. 2, pp. 367-384, 1988.

[2] E. G. Origoni, R. Bocchio, A. Boriani, M. Carmine, and L. De Capitani, "Late-Hercynian mafic and intermediate intrusives of Serie dei Laghi (N-Italy)," Rendiconti-Societa Italiana di Mineralogia e Petrologia, vol. 43, no. 2, pp. 395-409, 1988.

[3] A. Boriani, V. Caironi, M. Oddone, and R. Vannucci, "Some petrological and geochemical constraints on the genesis of the Baveno-Mottarone and Montorfano plutonic bodies," Rendiconti-Societa Italiana di Mineralogia e Petrologia, vol. 43, no. 2, pp. 385-393, 1988. 
[4] A. Boriani, E. G. Origoni, and L. Pinarelli, "Paleozoic evolution of southern Alpine crust (northern Italy) as indicated by contrasting granitoid suites," Lithos, vol. 35, no. 1-2, pp. 47-63, 1995.

[5] C. Poisiana, I graniti minori dell'Ossola inferiore: caratterizzazione tecnico-petrografica e loro usi nella storia, Tesi di Laurea in Scienze Geologiche, Università degli Studi di Milano, 2002.

[6] U. Zezza, "Il granito del Montorfano: coltivazione e sue caratteristiche tecniche," in Atti del Convegno Internazionale Sulla Coltivazione di Pietre e Minerali Litoidi, p. 36, Torino, Italy, 1974.

[7] M. Pieri, Marmologia. Dizionario di marmi e graniti italiani ed esteri, Hoepli, Milano, Italy, 1966.

[8] G. A. Dino, A. Gioia, M. Fornaro, and S. Bonetto, "Monte Bracco quartzite dumps: chance of recovery as second raw material for glass and ceramic industries," in Proceedings of the 1st International Conference on the Geology of Tethys, pp. 203208, Cairo University, November 2005.

[9] B. Bigioggero, A. Boriani, G. V. Dal Piaz, and G. Martinotti, "Escursione: da Arona alla Val Formazza attraverso il Verbano, l' Ossola e le sue valli. Sosta 3.5.-Strada MontorfanoMergozzo, granito di Montorfano con filoncelli aplitici," in dal Piaz G.V., Guida geologica. Vol. 3/1: Le Alpi dal Monte Bianco al lago Maggiore, Ed. BeMa. Collana: Guide Geologiche Regionali (reprinted), 2004.

[10] G. Bozzola, L. Garrone, L. Ramon, and D. Savoca, " Un esempio concreto di riutilizzo di prodotti di scarto: da granito da discarica a materia prima per ceramica e vetreria," Ghaziabad Engines and Machines, vol. 4, pp. 17-19, 1995.

[11] H. M. Schiechtl and G. Sauli, "Nuove tecniche di bioingegneria nei ripristini di cave e miniere," in Atti Convegno Suolo e Sottosuolo, vol. 3, pp. 1347-1356, Associazione Mineraria Subalpina, Torino, Italy, 1989. 

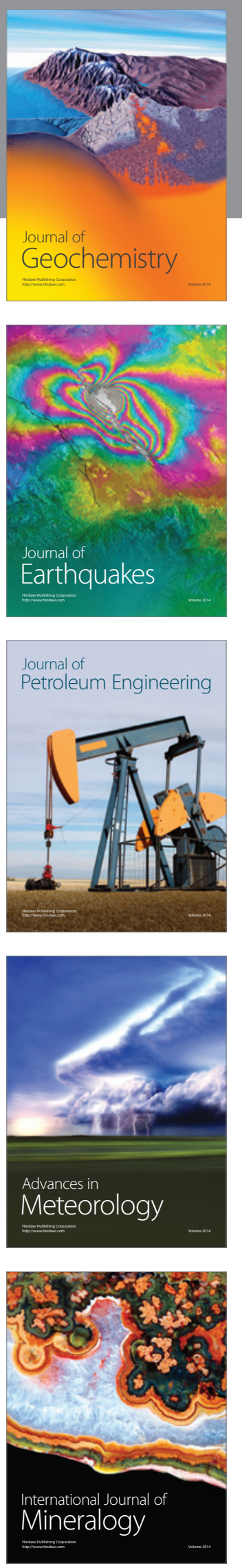
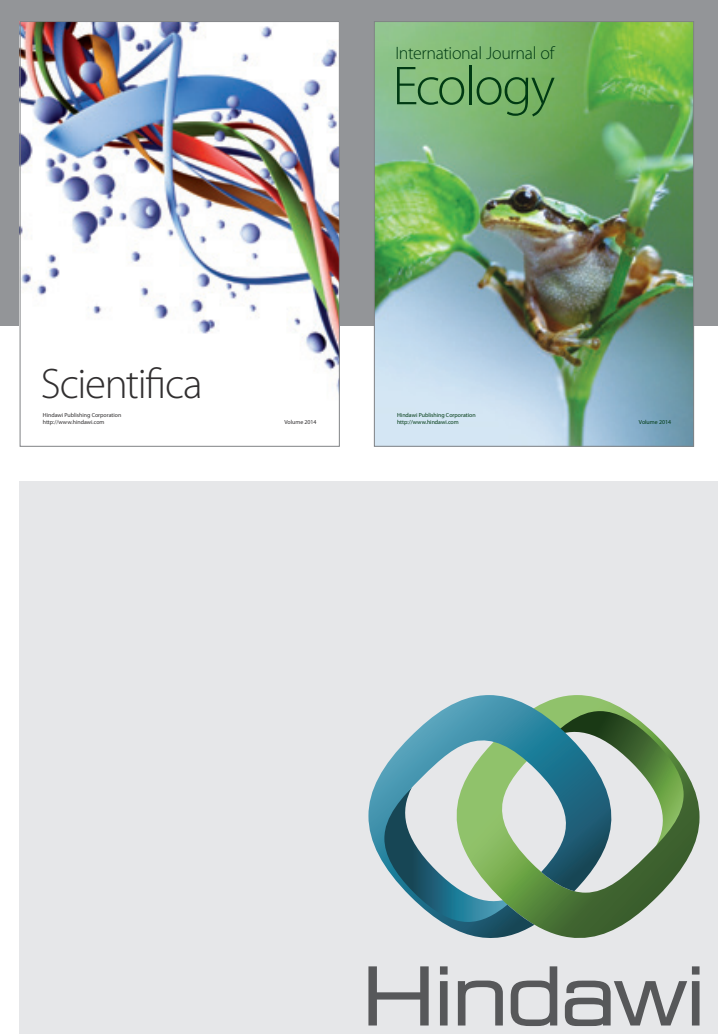

Submit your manuscripts at http://www.hindawi.com
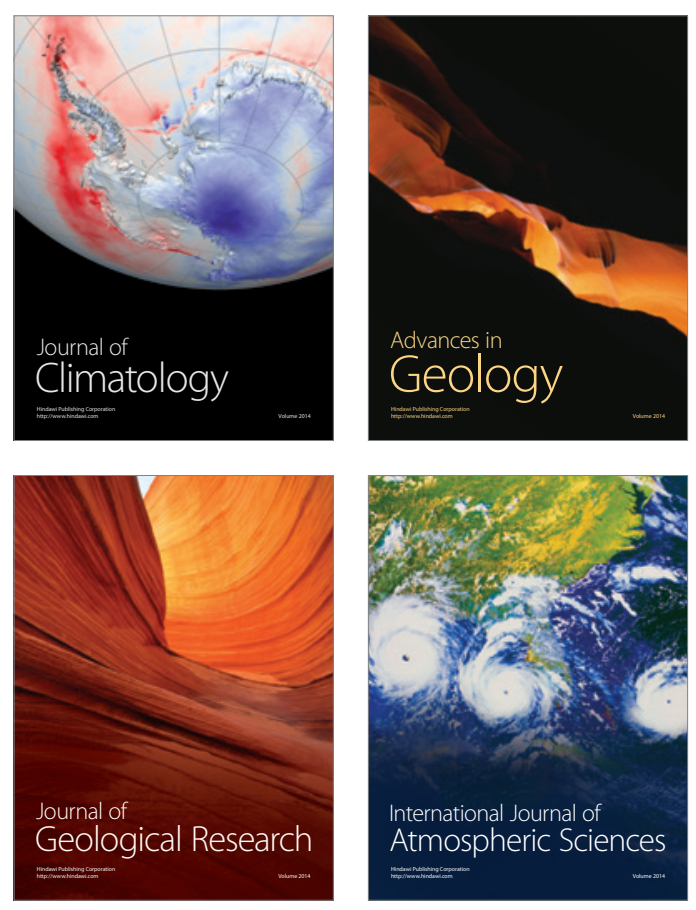
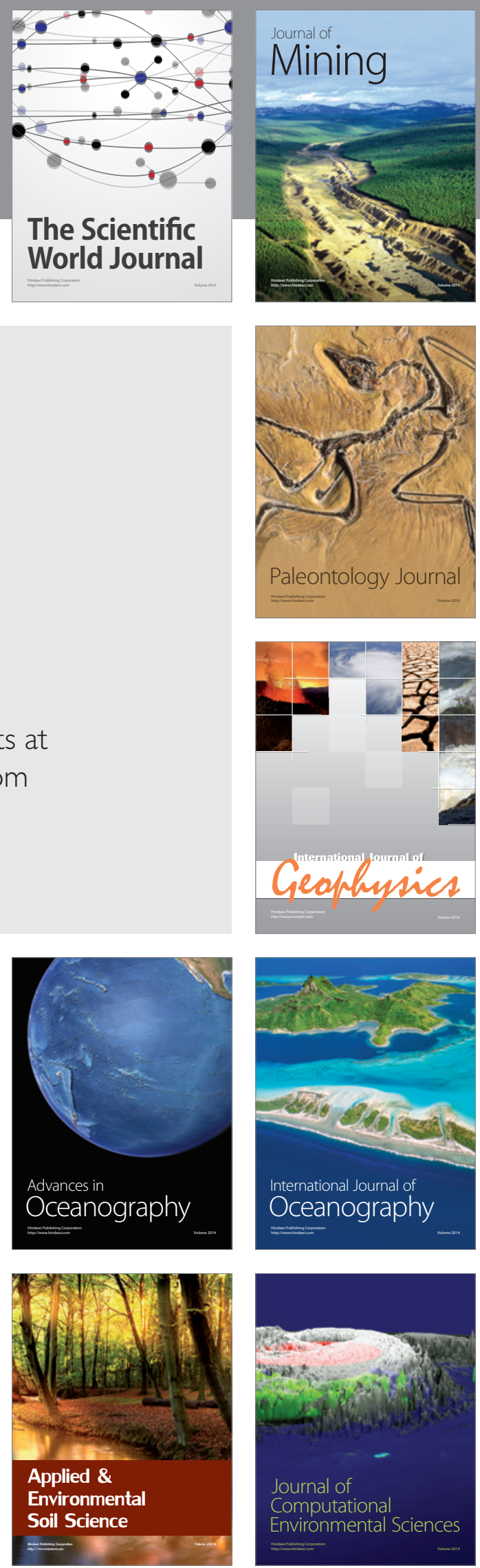